\title{
THE AUTOBIOGRAPHICAL EFFORT: IN SEARCH OF THE PERSON WITHIN
}

Dilvo I. Ristoff

Two major and contradictory forces are at work in what critic William Andrews (1992) once called "self-life-writing," his literal translation for "auto/bio/ graphy": (1) the attempt to register with accuracy, with fidelity to life or "intellectual and emotional veracity," as Ellen Glasgow (1954) puts it, the so-called "facts" of the past, and (2) the need to place these "facts" within the frame of purposeful narrative-an effort which invariably leads to the organization of autobiographies around one major question: "What have I lived for?" In the answer to this question, autobiographies seem to find their justification, so that the emphasis upon a few facts out of a world of possibilities may be regarded as support material for the construction of a self intended to be preserved, a self which, to use Nathalie Sarraute's words, is very often no more than "a cardboard model that reproduces on a small scale what the buildings, houses, temples, streets, squares and gardens of a submerged town must have been like" (quoted in Leibowitz, p. xvii).

Perhaps the best illustration of what I am trying to say is not to be found in modern autobiographies but in the Platonic dialogues, especially in dialogues like the Apology (or Socrates's Defense) and in Crito, Socrates's decision to defend not his body but his soul. True,

\begin{tabular}{|l|l|l|l|l|}
\hline Ilha do Desterro & Florianópolis & $n^{\circ} 39$ & p.125-146 & jul./dez. 2000 \\
\hline
\end{tabular}


what we learn about Socrates comes through the pen of Plato, but I would argue, along with James Olney (1988), Jill Ker Conway (1998), and others, that what is being biographed is most of the time exactly this: a kind of dummy who speaks through the voice of a ventriloquist, a person who expresses him or herself through a persona. Not to mention that the story of Socrates could also be read as a sort of inner script by which Plato chose to live his life. In the Apology, for instance, we have Socrates, the first evaluator of the academy, trying as best as he can to defend himself of the accusations made against him. What Socrates is being accused of (not believing in the Gods and corrupting the young men of Athens) is in retrospective less important than his effort to systematically construct his life story as that of a man determined to affirm values, that is, to affirm the values which he believes make life worth living: the search for truth, the search for beauty, and the search for social justice.

Socrates, so we learn, had been told by his boyhood friend Chaerephon that the Gods at Delphi had told him that he, Socrates, was the wisest of men. Aware that Gods, in principle, don't lie (it is not of their nature to do so), yet knowing also of his own limitations, Socrates decided to go on a pilgrimage to disprove the gods. So he first met with the politicians, especially with those held in great esteem for their wisdom, and began to question them. He soon discovered that their reasoning was circular, that they didn't know how to define basic words, and that they did not understand some very elementary concepts about life in society. What was worse, however, was that not only were these men not wise but they thought they were wise. Socrates concluded that in comparison with them, the Gods were right; he had indeed a slight advantage over the politicians, for he at least was aware that he had nothing to boast about when it came to wisdom. As Socrates mentions in Cratylus, "the worst of all deceptions is self-deception."

He then decided to try the poets. "The poets," thought Socrates, "must be wiser than I am. I'm sure that this time the Gods made a mistake. The poets write such wonderful things which we all admire. 
They must be wise." ${ }^{11}$ So, he went and talked to them. He showed them some of their best-written passages and asked them what they meant, hoping to be enlightened. To his astonishment, he discovered that anybody could have given a better explanation of the meaning of their works than the poets themselves. He discovered then that the poets did not produce by virtue of wisdom but by inspiration, by a kind of genius. They were like seers, prophets, and fortune tellers who also say marvelous things but have no idea of the meaning of what they are saying. Socrates, thus, concluded that in comparison with the poets, the gods were right, especially because they too thought of themselves as wise when they were obviously not wise.

Last, he decided to question the skilled craftsmen of his town, people who probably today would be comparable to our doctors, pharmacists, engineers, architects, dentists, and the like. "The Gods must be wrong," he thought, "for these men know things about which I don't have the faintest idea." And with these men he was not wrong. They indeed knew so many wonderful and useful things whose workings remained a mystery to Socrates-a man of no technical qualifications. But Socrates also perceived in the character of these men a terrible flaw. Because they knew everything about some things, they thought that they knew everything about all things, even about matters of which they knew next to nothing, things of the spirit, of life in society and everything else on earth and in heaven. And this defect in their character was so serious that it completely overshadowed their virtue. So Socrates, having decided that it was better not "to be wise with their wisdom neither stupid with their stupidity," turned himself into a spokesman for the oracle. "It is not that I am wise" thought Socrates, "but it is obvious that the Gods are using me as a metaphor to say that wise is he who, like Socrates, has realized that in respect to wisdom he is really worthless" (9).

Perhaps the most remarkable attempt to construct a defense of a life and a soul, not a body, through the affirmation of values, is Plato's dialogue Crito, in which Socrates, having just been condemned to death, 
receives the visit of his friend, Crito, in prison. His friend tells him that he should not worry, that all is ready, that the guards can be easily bribed, that the boat that will take him into exile is waiting for him, that all his friends have organized a detailed escape plan. What does he think!? To Crito's surprise Socrates refuses the offer to escape. He cannot, he argues, live in exile after having lived all his life among his people, after having taken part of the city's life and having helped to make its laws and educate its people. The laws are not wrong, he argues, even though faulty judgments may be passed as in this particular instance. What will happen with the state, he asks, if each one of us takes upon himself not to obey the law every time he dislikes a decision? "Do you imagine," he asks Crito, "that a city can continue to exist and not be turned upside down, if the legal judgments which are pronounced in it have no force but are nullified and destroyed by private persons?" Socrates, thus, does two things: (1) he affirms the values which he believes make the life of an individual worth living and (2) he affirms the values which promote social cohesion. His respect for the legal system as the thread which holds together the social fabric presupposes a paradoxical submission of the individual to the state as long as the participation of the individual in the construction of the laws can be assumed. His willingness to sacrifice his life for the survival of the state, however, suggests that Socrates values the individual much less than intellectuals in the American tradition, especially if one thinks of Thoreau's Civil Disobedience or Whitman's "Song of Myself." As George Gusdorf (points out, "the concern, which seems so natural to us, to turn back on one's own past, to recollect one's life in order to narrate it, is not at all universal. It asserts itself only in recent countries and only on small part of the map of the world ... This conscious awareness of the singularity of each individual life is the late product of a specific civilization" (Crouser 19).

Since so many argue in the same direction, let me now make a little historical jump of some 2,000 years, to say that it is certainly no accident that two of the most powerful texts of modern autobiography 
appeared at about the same time as the American and French revolutions-a time of affirmation of a new social order, of new rules of social mobility and therefore also a time of affirmation of the individual, his rights, especially his rights to life, to liberty, and the pursuit of happiness, as expressed in the Declaration of Independence, or the rights to a life with liberty, equality, and fraternity among men, as the French revolutionaries wanted it. According to William Andrews (1992) and G. Thomas Crouser (1989), who look at the genre from an American perspective, "autobiography and America were made for each other" (7), since it could only have originated within the realm of a society willing to do away with the repression of the individual, a repression historically imposed through socio-economic, cultural, and political structures which virtually forbade social mobility from happening and denied individuals the right to control their own destinies. In other words, autobiographies paradoxically promote the values of individuality while defending a form of social organization which assures that individualities have the right and perhaps the duty to manifest themselves without restraint.

Robert F. Sayre ("Autobiography and America") and Herbert Leibowitz (Fabricating Lives, 1989) argue in a similar fashion. Sayre states that American autobiographers generally "connected their own lives to the national life or to national ideas," whereas Leibowitz argues that the flowering of autobiography is more than an expression of America's "insatiable appetite for gossip" (xix). For him, the grand theme in autobiography is always "the quest for distinction" (xix) something he considers natural for a country which abandoned inherited titles and aristocratic ranks and that therefore saw in the competition for distinction the only way to receive recognition.

True or not, as Andrews points out, it is no doubt remarkable that Rousseau's Confessions (1784) and Benjamin Franklin's Autobiography (1986) should timewise be coincidental with the great revolutions in the US and in France. Yet both texts, although a tribute to individuality in their own particular fashion, are quite different when it comes to the 
relation of the individual to society. Rousseau not only denounces the societal standards which force him to follow the rules of conventional behavior and thus uses his text as an anti-aristocratic propaganda piece of sorts, but he also stresses that worse than violating the laws of society is to capitulate to its corrupt standards.

With Benjamin Franklin, who sets the tone for American autobiography, quite the opposite seems to be the case. Although here individuals are found wanting and not society, requiring an affirmation of virtues which will improve them and make them better citizens, the value affirmed is also social, since the purpose is not only the fulfillment of the self but also the improvement of the community through the individual. Franklin, quite obviously, wrote his autobiography not to attack society but to show that the conflicts between individual needs and desires have to be balanced with those of society at large. The excesses of unrestrained individualism can only be controlled by respect to social norms. Although Franklin's name is generally associated with rugged individualism, especially that of individualists like Jay Gatsby, that is, as the archetypal American apostle of success" (Andrews 10), his concern for the social order and for the construction of a positive image of his country is permanent. It is thus not surprising to hear him tell of his care, for example, to remove inconvenient pieces of news from the American newspapers before passing them on to his European friends when he was ambassador in France. This Socratic gesture may not be accidental at all, especially if one remembers that one of his stated goals in life was to "imitate Socrates."

My concern, however, is not with Socrates or Franklin, but with the identification of the purposiveness associated with the autobiographical genre-a purposiveness which in many ways remains fundamentally unchanged, despite historical distance and class, gender, and race differences. As V.S. Pritchett says, "There is no credit in living; the credit is in being able to specify experience" (quoted in Leibowitz, p. xviii). And I would argue, along with Crouser, that, in a sense, autobiography is always "done with mirrors;" that is, it tends merely to 
reflect prevailing cultural values and assumptions when specifying experience, and that, at a higher level of abstraction at least, these values seem to be, like autobiography itself, always in the making, always redefined rather than replaced.

In order to test my idea, I chose to briefly consider the autobiographies of four American writers-Frederick Douglass (African-American), Ellen Glasgow (woman), Philip Roth (JewishAmerican), and John Updike (white, Anglo-Saxon, Protestant, male). I would like to suggest, through some examples, that all these writers tend to associate themselves with the previously mentioned fundamental purposiveness - the affirmation of values which, at their particular time and from their particular socio-economic and cultural perspectives, represent also the affirmation of humanity itself.

Let me start with Frederick Douglass. His narrative was quite evidently published and used as an anti-slavery tract intended to win public support for the abolition of slavery but, as Andrews points out, it was written "as a testament by a slave"(vii). Andrews is quite emphatic in his argument that "for Douglass the book had a private importance beyond its public usage. It declared him, in print, to be a man of intellect. The book existed to rebuff the idea that an African slave was a brute without the capacity to write eloquently. The title page read Narrative of the Life of Frederick Douglass, an American Slave, Written by Himself; that, in the nineteenth century, was the standard device for saying my book is mine and not as-told-to or ghost written" (vii). There is then a commitment to affirm a selfhood, by telling his story himself, in print. Learning to read and write were absolutely instrumental in the process of his escape from slavery and in his understanding of the predicament which slavery imposed upon him. As he puts it in his narrative, "I have found that, to make a contented slave, it is necessary to make a thoughtless one. It is necessary to darken his moral and mental vision, and, as far as possible, to annihilate the power of reason"(64-65). Here it might be worth recalling that, after the success of his first autobiography, Douglass wrote two more 
autobiographies-My Bondage and My Freedom and Life and Times of Frederick Douglass, the last of which also enjoyed great success.

Thus, we should perceive that Douglass' narrative follows a dual path: (1) the struggle for affirmation and recognition of selfhood and (2) an indictment and a call for redefinition of a social system. His path is therefore different from that of Socrates or Franklin (insiders determined to define themselves within the system) and more like Thoreau and Rousseau (who define themselves in opposition to the system), as I would argue is the case with most autobiographies written by authors who originate from minorities. Yet, Douglass' opposition to the system of slavery of the South somehow affirms the system of the North of which he gladly wants to be recognized as a member.

With regards to Douglass' affirmation of selfhood, it is worth recalling first of all his insistent need to declare himself quite simply a human being: "I was born in Tuckahoe ... Maryland ... My mother was named Harriet Bailey ... My father was a white man (12) ... I started from Baltimore bearing the name of 'Stanley.' When I got to New York, I again changed my name to 'Frederick Johnson,' and thought that would be the last change. But when I got to New Bedford, I found it necessary again to change my name. The reason of this necessity was, that there were so many Johnsons in New Bedford, it was already quite difficult to distinguish between them. I gave Mr. Johnson the privilege of choosing me a name, but told him he must not take from me the name 'Frederick.' I must hold on to that, to preserve a sense of my identity. Mr. Johnson had just been reading the 'Lady of the Lake' and at once suggested that my name be Douglass. From that time until now I have been called 'Frederick Douglass'." (72)

Douglass struggles with this need to establish his origins and his identity. His uncertain fatherhood, his lack of a family identity "slavery has no use for either fathers or families" - (103), leaves him at freedom to strip himself of middle names and last names for they help little to define his true identity, his distinction, as an individual, which explains why his first name is kept despite the possible risks it may 
entail. His new last name, furthermore, is not simply an attempt to pave his way to safety; it was carefully chosen to identify his self with Sir Walter Scott's Lord Douglas, the wrongfully exiled Scottish chieftain who was "revered for his bravery and virtue" (Andrews 72). This intellectual connection shows that Douglass is closer to the northern white man's system than one could suppose, sharing not only the white man's aristocratic nostalgia, the Franklinian values of efficiency, but also his artistic and intellectual ambitions and search for distinction. By writing his autobiography, Douglass denounces the injustice and inhumanity of slavery but also prepares the ground for his own assimilation by the northern white society, with all that it entails.

Ellen Glasgow's The Woman Within, published after her death, in 1954, is another such example of a particular reconstruction of the past with a purpose. It is not a mere transposition of the world of facts from a supposedly existent text of reality to the reality of the page, but rather, a finger pointing toward a way which tells us how we should feel about what has been chosen as the object of narration. It is thus, much as Glasgow herself suggests, an exercise of memory and imagination, for "how can one tell where memory ends and imagination begins" (281). And we could add that the act of imagining involves probably more forgetting than remembering. As Pamela Mathews argues, "The Woman Within can and should be read skeptically as truth... [for] autobiography springs from a false impulse to comprehend a unitary self"(xxvii).

It is, therefore, in many ways, a self-defeating exercise to question whether the "facts" selected as the basis for Glasgow's reports are true or not, because what begins on the presumption of self-knowledge soon proves to be the creation of a fiction whose premises of construction can be found without great effort (xxvii). The more appropriate question is, thus, to what purpose were the reported facts slanted? The immediate answer is: to add sharpness of definition to an imagined woman within.

And where is the woman within to be found? Pamela Matthew's reading of the Autobiography may be correct when she says: "In 
Glasgow's The Woman Within, [we should perceive that there is] in her narrative of exile a vision of community; in a narrative of rebellion a longing for acceptance; in her narrative of irony and cynicism a truth of vulnerability; and in a narrative of exceptionality a desire for ordinariness" (xix).

The large number of examples referring to her illness, her headaches, her hearing problems, her isolation, her father's incapacity to show affection, her love of pets, her looking through the window to watch the more robust children play in the street, her pain at the ridicule of her first poem, her very attempt to become a writer and be willing to communicate something to the world-all these and many other examples illustrate that, in her frailty, indeed, she longed for community, acceptance, ordinariness-that "common humanity which sustains friendship" (232). Although part of a well-off Richmond family, Glasgow lives the paradox of perceiving herself as an outsider.

Yet, what Glasgow terms ordinariness seems to be motivated by passions which we generally associate with values pursued by the greatest of human beings: the search for truth, the search for art, the search for reality, the search for love, and pity for the suffering of living creatures.

The search for truth led her to look for explanations for the social and economic predicaments of mankind. She studied social history, theories of economics; she studied John Stuart Mill and Charles Darwin until she almost knew their texts by heart. It led her especially to books that her father and her eldest sister feared and hated, because to them they seemed to destabilize the system.

The search for art had been with her since she was a child and tried writing her first poems, and it continued throughout her life in a constant Franklinian toil for personal improvement. After the publication of her first novels she actually started studying great authors (Tolstoy, Flaubert, Maupassant, Fielding, etc.) in the hope that she might conquer art and beauty and so escape "from the particular into the general, from the provincial into the universal" (128). 
Her search for reality is described as a descent into the world of philosophy. "I turned then to philosophy, not in the modern sense, but as the ancient decreed pursuit of the highest good" (171). She turned to the neoplatonist Plotinus, to Kant, Shopenhauer, Santayana, Berkeley and Hume, the Upanishads. Her search for truth meant ultimately a profound involvement with religion - an attempt to escape from herself, "to lose herself in something greater than herself" (174). Needless to say that what she calls reality looks more like the reality of the platonic forms than common sense perceptions of one's surroundings.

Her search for love was, in fact, a frustrated search for ecstasy. "From the beginning," she writes, "I was to discover that, if physical instincts did not bother me, the illusion of romantic love was an ancient antagonist" (56). In other words, the longing for love was always in the way of tranquillity. But, since romantic love was never more than a passing sensation, Glasgow's intellectual activities led her to believe that "the life of the mind [was my] reality" (163). This anesthesia of the heart became also a numbing of her sexual instincts, so that she would later claim that "I should have found wholly inadequate the mere physical sensation" (163). The search for love, it should be said, was later dislocated to another search. Falling out of love may not have brought bliss itself but it brought "blissful tranquillity," the freedom she needed to be able to produce her best work.

Finally, her manifest pity for the weak and unprotected, be they dogs, horses, animals in general, trees or human beings, seems to have been a trait of personality which translated itself into ideology. Her abhorrence of President Theodore Roosevelt's game hunting in Africa (we could add Brazil), of her father's cruelties toward animals and toward her brother, her dislike of war, her wondering at the fact that "people do not rebel when they have nothing to lose" (80), her becoming a socialist-all these are indications that the things she searched for most in life were somehow also anchored in the suffering of humanity and living beings in general. 
These are some of the ideas which I believe somehow portray the woman within which Glasgow wants us to see. Extraordinary or not, the life she has reconstructed and thinks she has lived shows paradox at its best. After all, Glasgow is the insider who abhors the inside, a socialite who feels ostracized, the outsider whose outside never quite materializes, a child at once loved and misunderstood, a rebel who doesn't rebel, a lover who never truly loves, a mind tortured by loneliness, uncertainty, curiosity, confusion and by the complications of a life lived in secret freedom. The confusion may have its roots in the conflicting origin within her family, her mother stemming from the old southern Aristocracy and her father an offspring of the new industrial south, something which Glasgow both admired and disliked. Woman Within is, thus, Glasgow's attempt to explain to herself and to her readers why she turned to writing and how, through it, she managed to affirm the values she imagined worthy of a life well lived.

Philip Roth's Facts, published in 1988, is remarkable in the sense that it is already clearly the product of the post-modern crisis of representation. Roth, whose fiction work in general has been identified as highly autobiographical, decided to write about the "facts" of his life in a form that even on surface looks like fiction. His facts are emplotted in such a way that little doubt remains from the start that we are faced with just another piece of his life, this time hidden behind the persona of Philip Roth. He writes his text, and once he considers it finished, mails it, along with a long letter, to Nathan Zuckerman, the protagonist of his famous Zuckerman tetralogy. Zuckerman reads it and writes a 35 page long letter back to Roth, commenting on the autobiography and recommending that, because it is less real than himself, it should not be published. What Roth does, instead, against the advice of his own creation, is publish it, not only with his letter to Zuckerman but also with Zuckerman's reply, so that what we actually get is not only the autobiography but also a double self-reflection about it, one by Roth, the persona, and one by Roth, the fictional personage, if we can make such a distinction. 
Claiming that in the past his imaginative works had always started with the facts, that his fiction always sprang from facts, this time, in his autobiography, he has written a book backwards, that is, moving from imagination to fact rather than from fact to imagination, "taking what I have already imagined and, as it were, desiccating it, so as to restore my experience to the original, prefictionalized factuality"(3). The book is then imagined as his counterlife, "the antidote . . . to all those fictions that culminated in the fiction of [Zuckerman, David Kepesh, and others]" (6). Having for thirty years fictionalized his life, Roth decides at 55 he wants to undress the facts of their fiction, to distill the facts from their fictive impurities, to go back to "the original well"(6). What he wants is to render experience untransformed. He admits to Zuckerman that this may sound naïve coming from a writer who has never conceived of a life without fiction, yet he sees it as a worthy exercise for two major reasons: (1) because it works as a kind of therapy, an attempt to try to explain himself to himself [to understand why he is what he is, lives where he does, why he became a writer, etc.], and (2) because it explains to the Jewish elders of his community who "this kid was who was writing this stuff"(4).

Did he find the original well he was looking for? Did he manage to render experience untransformed? Not quite. Answering his own questions he says that, counter to his expectation, he found not one moment of origin but a series of them, a "history of multiple origins" (5). In his struggle to repossess himself without fiction, he writes, "I came to believe that I just could not make myself over yet again. Far from feeling capable of remaking myself, I felt myself coming undone" (5). As he tells us, he finds himself resisting the temptation of "undermining experience, embellishing experience, rearranging and enlarging experience into a species of mythology . . . dramatizing untruthfully the insufficiently dramatic, complicating the essentially simple, charging with implication what implied very little-, [in fine], the temptation to abandon the facts when those facts were not so compelling as others I might imagine"(7). Needless to say, he changes 
names of people and places, dates, and identifying details, falling back into the trap of fictionalizing facts, lost, as Fichtelberg would say, in the "labyrinth of language."

Aware that "memories of the past are not memories of facts but memories of your imaginings of the facts"(8), he realizes that the effort in the end has only unlocked another meaning of himself, so that all he can finally ask of his fictional character is if, after all these difficulties with the genre, his "book is any good" (10).

Zuckerman's reply starts emphatically: "Don't publish-you are better off writing about me than 'accurately' reporting your own life" (161). Why? Because, for one, Zuckerman, much in the vein of John Starruck, who argues that, even when he lies, "it is impossible for an autobiographer not to be autobiographical" (21), demands his due place in Roth's autobiography. He claims that he is much more than a means Roth uses to detach himself from facts. He, too, is 'fact,' but 'fact' made interesting. This autobiography, he thinks, is simply not interesting. "In the fiction you can be so much more truthful," he tells his creator. He, thus, complains that indeed Roth had done a good job trying to keep imagination out of his book and that, because of this, the book is boring; that is, the autobiography is, well, what you get when you meet Roth without Zuckerman, or Roth without imagination.

Roth is, then, not only writing an autobiography but also looking at himself writing it. It is not that he rejects the classical search for truth, beauty and justice-it is that he has difficulty in expressing the same old Socratic certainty about an immanent meaning for these words. He has come to doubt that there is a Roth that is not personified; that there is a father-son, mother-son, husband-wife, artist-art relationship; that there is an American identity, a Jewish-American identity, a Jew-Gentile relationship that is not somehow tainted by and emplotted according to individual and group interests; that there is, in short, such a thing as ethics without aesthetics and vice versa. He has come to realize that perhaps Nathan Zuckerman's father was right when he complained to his son that "people don't read art; they read about people," and that, 
therefore, his book was offensive to the Jews. Thus, The Facts affirms more than an individuality: it affirms along with the artist, the crisis of identity of somebody struggling with the iconic values of country, community, and family at a very specific moment in history.

Roth's autobiography, finally, corroborates James Olney's notion that since the past is always lost, autobiographers must impose a pattern on memory, and that, although the facts are past, the pattern is always present and serves to explain as much one as the other. In Roth's case, this pattern goes beyond the usual realization that the autobiographer is at one time subject and object of the effort involved. Certainly influenced by the trend of the times, Roth dramatizes the postmodern crisis of representation, aware that "the search for an autonomous self always leads to a language that predates it and that constitutes it in its very make-up," as Terry Eagleton so well puts it—something, it must be said, quite unusual for a writer generally associated with the neorealistic trend of contemporary American fiction.

John Updike's Self-Consciousness, published in 1989, that is, a year after Roth's Facts, claims to be self-conscious from the title. Most of the text appeared in full originally as self-contained pieces in various national magazines, especially in The New Yorker.

What is striking from the start in Updike's autobiography is his juxtaposition of quotations by Emerson and Virginia Woolf as his epigraphs. From Emerson he quotes: "we are persuaded that a thread runs through all things, all worlds are strung on it, as beads: and men, and events, and life, come to us, only because of that thread" (Emerson, "Montaigne; or, The Skeptic"). From Virginia Woolf, he quotes: "I find myself saying briefly and prosaically that it is much more important to be oneself than anything else" (Virignia Woolf, "A Room of One's Own"). In other words, what we have here is an attempt to emplot factuality in terms of "a specimen life," or as something or somebody that is paradoxically unique and yet representative of all lives. To achieve representativeness, emplotment, selection, omissions, emphases have to be created; to achieve uniqueness, it is fundamental 
that some basic respect for the actual and factual experience of the individual be considered, even as he elusively transforms himself or emplots himself into appearing to be what he actually is.

After a long description of his hometown in Shillington, Pennsylvania, for example, Updike realizes that he hasn't described the town inhabited by Shillingtonians at all, but only his own town "a few scraps preserved by memory and used more than once... used up and wished away in the self-serving corruptions of fiction"(40). Yet, despite his admitted interference of the self-serving corruptions of fiction which led him astray from what he thought he was doing, his observation leaves him wondering at his own realization of self-hood:

"Isn't it a miracle," he asks himself, "the oddity of consciousness being placed in one body rather than another, in one place and not somewhere else, in one handful of decades rather than in ancient Egypt, or ninth-century Wessex, or Samoa..., or Bulgaria... Billions of consciousnesses silt history full, and every one of them the center of the universe" (40).

Aware that "selves are conditional and die" (233) and aware of the impossibility of pinpointing a self that he can say is his, especially because to a large extent he always thought of his past and future as never quite his own idea, Updike breaks up what he thinks he is or was into many selves: a childhood self, a high-school self, a Harvard self, an Ipswitch self (a "delayed second edition of the high-school self, a mini-Mailer self), the $\mathrm{New}$-Yorker self, the famous-writer self, the oldage and deteriorating self, aware, however, that there is some matrix material which flows through all of them and which he cannot grasp, not because it is not there, but because we have ceased to pay attention to it, like the mind which can only go to sleep when it ceases to pay attention to itself, or as he puts it elsewhere, like a tree or a person that grows and yet never forgets to remember what or who it is. Updike's 
"I" is thus much like the "dot-matrix I" or the "pixels dancing on a video screen" that Crouser talks about in his book Altered Egos-a tenuous configuration or a steadiness of image only produced by the "speed of the scanning beam" (18).

What I consider particularly interesting, however, is that Updike, the white, Anglo-Saxon, Protestant male, supposedly the center, wants us to believe that he lived a life in permanent conflict with his acute sense of shelter and his appetite for the outside. His being the son of a schoolteacher gave him, for example, the sense of being somebody in the community; the financial difficulties of his family which forced them to live on a farm with his grandparents, on the other hand, gave him the feeling of being an outsider. This sentiment of not being a full participant of his community was also largely triggered by his skin disease, psoriasis, which played a major role in his life, actually determining every major aspect of his life, including his decision to move to Ipswitch, Massachusetts, to become a professional writer. His need to be always on the lookout for a letter in the mailbox, to reach out and search for his readers is to a large extent an expression of his need to present himself to others as pleasant and beautiful, especially because he imagined himself as "monstrous" a good part of the year. This outsiderness could also in some way be extended to intellectual and political terms. In the sixties, when most of the Academia was protesting the Vietnam war, when hippies and civil rights activists were invading his home, taking his wife with them, smoking pot, wearing dashikis, bell bottom pants, love beads, and Afros whose limit was the sky, Updike was one of the few who, like middle America, was for the war and spoke openly in its defense. Thus, although a defender of the ideology of the center, that is, of the heartland of America, Updike felt like an outsider because his intellectual curiosity, his social life, his academic ambitions, had led him way beyond the narrow interests of middle America. America's national divisiveness during the sixties thus coincides with Updike's personal determination to become a writer, and the ambiguities of the country never seem to have left him, for he 
was never quite able to give up the idea that the center must hold and that it is, therefore, worth protecting it, while he recognized the importance of flirting with the marginal forces which turn the wheels of history. As he puts its, "I was happy enough to lick the sugar of the counterculture; it was the pill of anti-war, anti-administration, antiimperialist protest that I found oddly bitter... I thought it ... shocking that so many Americans were gleeful at the crash" (129) "It greatly distressed me, for example-it wasn't fair-that American liberals could so blithely disown what was clearly a typically and historically liberal cause, intervention against a Communist bully" (130). Written from the vantage point of the post-Reagan, post-cold war era, Updike's text becomes a Socratic self-defense, an attempt to justify his political views to himself and to a nation now victorious over the national enemy who for so many decades gave Americans a reason to get up in the morning. It is, therefore, as much an affirmation of social values and a search for recognition as it is, once more, a manifestation of what I identified at the beginning of this discussion as the underlying theme of autobiographical efforts in general. As Jill Ker Conway puts it in her recently published book When Memory Speaks (1998), "Every autobiographer wants to persuade others to learn from her or his life. Most aim to convince their readers to take up some important cause, follow a new spiritual path, be aware of particular hazards, develop a new moral sense ... so that while we think we are reading a gripping story, what really grips us is the inner reflection on our own lives the autobiographer sets in motion"(16-17). In other words, in every autobiography there is an attempt to answer the question "What have I lived for?" or, phrased differently, "What do I think life should be lived for?"

This leads me to conclude this essay with what I consider to be the most complete practical application of what I have been trying to say. What I'm talking about is an excerpt from Bertrand Russel's long autobiography. In this text, Russel writes: 
"Three passions, simple but overwhelmingly strong, have governed my life: the longing for love, the search for knowledge, and unbearable pity for mankind. These passions, like great winds, have blown me hither and thither, in a wayward course, over a deep ocean of anguish, reaching to the very verge of despair.

I have sought love, first, because it brings ecstasy-ecstasy so great that I would often have sacrificed all the rest of life for a few hours of this joy. I have sought it, next, because it relieves loneliness-that terrible loneliness in which one shivering consciousness looks over the rim of the world into the cold unfathomable lifeless abyss. I have sought it, finally, because in the union of love I have seen, in a mystic miniature, the prefiguring vision of the heaven that saints and poets have imagined. This is what I sought, and though it might seem too good for human life, this is what-at last-I have found.

With equal passion I have sought knowledge. I have wished to understand the hearts of men. I have wished to know why the stars shine [why the plants grow or why the eyes can see]. A little of this, but not much, I have achieved.

Love and knowledge, so far as they were possible, led upward toward the heavens. But always pity brought me back to earth. Echoes of cries of pain reverberate in my heart: children in famine, victims tortured by oppressors, helpless old people a hated burden to their sons, and the whole world of loneliness, poverty, and pain make a mockery of what human life should be. I long to alleviate the evil, but I cannot, and I too suffer." And Russel concludes: "This has been my life. I have found it worth living, and would gladly live it again if the chance were offered me." 
It is this affirmation of love, beauty, knowledge, and justice-this affirmation of life values-sung through different melodies, styles, forms, and degrees of anxiety and certainty, that has been telling the fundamental history that has inspired autobiographies throughout time. If the human being is, as Socrates wanted it, moved by thumus - that high spirit which attributes values and tells us that the unexamined life is not worth living - then the search for recognition found in all serious autobiographies is also an affirmation of the values historically held in highest esteem by societies everywhere, namely the pursuit of happiness through the search for the truthful, the beautiful and the just, or if you want, for science, art, and justice.

Socrates used to say that all things have a function and a virtue. The function of a knife is to cut; its virtue is that which makes the knife perform its function well, that is, its sharpness. The narratives which encapsulate the life of autobiography are never a mere list of actions or functions performed in the past; they are always an attempt to pinpoint the virtues which accompany these functions and which are believed to have made a life worth living and deserving of the attention of the present and future generations.

\section{Note}

1 This is a free interpretation of Socrates's words in Plato's Apology.

\section{References}

Andrews, William, ed. Classic American Autobiographies. New York: Penguin, 1992. .ed. Narrative of the Life of Frederick Douglass, an American Slave, Written by Himself. New York: Norton, 1997.

. To Tell a Free Story: The First Century of Afro-American Autobiography, 17601865.Urbana: University of Illinois Press, 1986. 
The autobiographical effort: in search... 145

Batchelor, John, ed. The Art of Literary Biography. Oxford: Clarendon Press, 1995.

Conway, Jill Ker. When Memory Speaks—Reflections on Autobiography. New York: Knopf, 1998.

Crouser, Thomas G. Altered Egos-Authority in American Autobiography. New York: Oxford University Press, 1989.

Douglass, Frederick. Narrative of the Life of Frederick Douglass, an American Slave, Written by Himself. In Williams, Andrew. Classic American Autobiographies. New York: Penguin, 1992.

Fichtelberg, Joseph. The Complex Image: Faith and Method in American Autobiography. Philadephia: University of Pennsylvania Press, 1989.

Glasgow, Ellen. The Woman Within. Charlottesville: University of Virginia Press, 1954.

Leibowitz, Herbert. Fabricating Lives-Explorations in American Autobiography. New York: Knopf, 1989.

Lemay, Leo J. A. and Zall, P.M., eds. Benjamin Franklin's Autobiography. New York: Norton, 1986.

Mathews, Pamela, ed. Ellen Glasgow The Woman Within-an Autobiography. Charlottesville: The University Press of Virginia, 1954.

Mersand, Joseph, ed. Great American Short Biographies. New York: Dell, 1966.

Neuman, Shirley, ed. Autobiography and Questions of Gender. Alberta: Frank Cass, 1991.

Olney, James, ed. Studies in Autobiography. New York: Oxford University Press, 1988.

Plato. The Collected Dialogues. Princeton: Princeton, 1982.

Roth, Philip. The Facts. New York: Farrar, Strauss \&Giroux, 1988.

Russell, Bertrand. The Autobiography of Bertrand Russell: 1872-1914. London: George Allen and Unwin. 
Stull, James N. Literary Selves: Autobiography and Contemporary American Nonfiction. Wesport: Greenwood, 1993.

Taylor, Gordon O. Chapters of Experience-Studies in $20^{\text {th }}$ Century American Autobiography. New York: St. martin's press, 1983.

Updike, John. Self-Consciousness—Memoirs. New York: Fawcett Crest, 1989. 